\title{
The Ape-men of Mobongu
}

\author{
Herbert Astor
}

$\mathrm{T}$ he steam launch Seagull was ploughing her w'ay up the yellow Sepik River in the heart of Dutch New Guinea. No wilder place in the entire globe is there than that district surrounding the Sepik. Indeed, there are hundreds of square miles of that country which are entirely unknown and unknowable to men, white or black.

It was nearly midday, an impossible period in that locality for travel.

"What about making camp?" suggested young Bob Dane, who stood at the wheel. He spoke to his pal, Wally Horton, who lounged in the stern, and to Dr. Holt, the scientist, who was pottering around the engine.

"Good oh!" replied Wally, and the scientist nodded. Bob steered the launch into a shallow lagoon, and camp was pitched. These fellows were simply adventurers. Bob and Wally, lads not long left school, had wandered up from Sydney to the Edie Creek goldfields for a holiday. The excitement in that place soon petered out, and they had been left seeking fresh adventures elsewhere.

It was then that they had met Dr. Martin Holt, the scientist, who had been roaming about the wilds for years in his steam launch, in search of scientific data for a book. He was a companionable sort, and the boys liked him at once.

A few days after their meeting the doctor had said that he was going for a trip to the head waters of the Sepik, and invited them to join him. The boys jumped at it. The Seagull was a big vessel, and fitted splendidly. The scientist possessed a fine stock of guns, and niggers and everything to make a grand expedition.

But the voyage had been so far dull. except for hunting. They had covered 300 miles. The Aui Rapids, the termination of navigable water, lay less than 30 miles to the westward. It would be soon time to turn back to the coast.

The voyage had been dull to that point, and the boys were yawning over it when they landed in that lagoon to sleep out the fiercest heat of the day.

But it was not destined to remain dull. It was as if the hand of Fate had beckoned them on, for all that 300 miles of yellow water, to hurl them at last into the trap of monstrous perils which lay beyond.

At about three o clock they began to stir again. The native boys were getting stores out and lighting a fire, to prepare a meal. The white men lounged under a spreading mangrove. They felt as lazy as possible, and watched everything disinterestedly... But at that very moment the adventure which was to claim their every attention for many anxious days was at that moment hovering not twenty yards away.

"Pipe that large chook!" said Wally to the others, and pointed to a big black bird volplaning out of the sky. It settled on a limb of a tall dead tree. It was coal black, and in shape something like a giant domestic fowl.

Dr. Holt, who knew every bird and beast in the great mysterious land, looked at it with interest.

"That's a black buzzard," he said. "The best eating bird in New Guinea. It's rather strange that none of the natives will touch it, not even the pigmy tribes. They call it debildebil bird, whose soul will haunt them for evermore if they kill it. But to white men it is considered the best game in the bag. Its flesh is excellent, despite the fact that the bird lives to a great age. See if you can drop him."

Bob took up a rifle and stole into the jungle, while the others watched the perching bird from the camp. There was a report, and the buzzard, with a squawk and a frantic tlutter of wings, dropped dead.

A few minutes later Bob returned with the bag. "He's a whopper, isn't he?" he laughed, when he flung the dead bird down.

Dr. Holt turned it over with his foot, and the great black wings flopped out.

"Holy smoke!" cried Wally, suddenly, "What's that?"

Dr. Holt, with a quick exclamation, bent over the dead bird. "A gold plate!" he answered.

A thin slab of beaten gold was seen to be fastened beneath the left wing, being held in position by crudely-drawn wires of the same metal. 
"There's writing scratched on it!" the scientist said, as he quickly freed the plate and examined it. The metal was bright, and the scratchings were so faint that it was impossible to read them.

"I know," said Holt. "Give me the butter."

He took the buticr and smeared the gold plate with it; then. taking a piece of charcoal from the fire, he crushed this to powder, and rubbing it into the greasy metal, then cleaned the surface, and black letters appeared where only unreadable scratchings had been.

"Read it!" the scientist gasped.

The boys looked eagerly over his shoulder.

"I am a prisoner in the hands of an ape colony on the Hidden River. The bearings of the place are 5 south $x 130$ west. Save me. Colin Wills, Jan., 1915."

"By George!" cried Wally. "What's the meaning of it?"

"Perhaps it's a practical joke of some kind," put in Bob.

"No," said the doctor, quietly. "I don't think it's a joke. It flashed to my mind like that at first, but the person who sent that message has apparently taken many wise points into consideration. First, the message was written on a gold plate because gold will not tarnish in rain or sun, and the scratchings would not be obliterated in a hundred years. Next, the bird chosen to bear it to the world. Naturally. the sender would want his message taken to white men. He knew that the buzzard is sought after by white men. and yet the natives will not touch it. Then he considered the endurance of the buzzard, its long flights, and the age to which it lives. See?"

"Moreover." he continued, "I have heard whisperings among the natives about a so-called Hidden River in the hinterland. And among the pigmy races there are legends which tell of a tribe of Tak anu nu, as they call them, the greal hairy giants of an unknown place called Mobongu. To tell you the truth, I never believed such tales. Niggers taik a lot of nubish in their legenos. Anyhow, let's ask Ponkalo."

The scientisi czlled to the leader of the four pigmy guides who were wit: the party. He came over, and Holt began to talk to him in his own tongue. The pigmy began to gesticulate and jabber excitedly, frequently pointing to the south-west. His face expressed abject fear.

Holt translated to the boys what the native said. "He says that the Ape-men are spirit giants, the souls of monkeys which men have killed, come back to the world for revenge. They are very terrible. He has never seen any, nor has anyone he knows, nor his great-grandfathers for that matter. It is as recorded in their legends. No selfrespecting pigmy will venture south-west of the Aui Falls. He says that his ancestors, many years ago, knew them, and what they knew is quite enough for Ponkalo."

"Good heavens! I wonder if there's really anything in it," said Bob.

"Even if there was, it' $d$ be too late," Wally replied. "The date of the message says 1915. That's twelve years ago now."

Dr. Holt looked at the two boys silently for a while. When he spoke there was a tremor in his voice that betrayed suppressed excitement.

"If you boys will come with me-" he began.

"You bet your life we will!" they answered in one voice.

"Well, then, let's find the Hidden River if it really exists," said the scientist.

From a bag he produced a big map of the country. "See" (he pointed out their position), "where the rapids are, a wide range of mountains runs east and west. All due west of the rapids has been explored, but not down here south-west. The Aui Rapids are right in the foot of the mountains; therefore, if there is a Hidden River, it must come into here on this side of the rapids. See?"

The boys nodded. They were excited at the thought of the adventure before them. Nor was the excitement confined to them; the four pigmies, while chattering and gesticulating, were pointing fearfully at the white men. Evidently Ponkalo had told them about the Ape-men, and that Holt was going in search of them.

"I vote that we feed at once," said Holt, "and push on to the rapids before it gets dark. To-morrow we'll begin our 
search for the so-called Hidden River."

It took a week to find the inlet of the Hidden River. Dr. Holt found it by testing the power of the Aui Rapids at various points. He found that in one place the fall of water was more than twice as strong as in places above and ultimately located the mouth of the Hidden River, pouring out of a subterranean passage in the very centre of The Sepik. Not far away they found a hidden swamp, and, tracing it for about three miles came suddenly upon a great, swift yellow ribbon of water, flowing from the unknown heart of Dutch New Guinea, from the land of Mobongu, the abode of the Ape-men.

They rolled the Seagull to the swamp and, laboring and straining. with crowbars and logs, sometimes floating her, at others dragging her through the muddy jungle, they at last launched her into the Hidden River.

Two days after the discovery, the party set out on the journey to the south-west, not realising what wondrous adventure and dire peril lay before them. The pigmies had to be closely watched, for, so great was their fear that the tiny natives tried to bolt from camp when they realised what was the party's objective.

Sooner than expected, the party reached the domain of the Ape-men. On the first day, from dawn till dark, they covered a hundred miles, and when the sun went down, put into a clearing beside a lagoon to camp for the night.

At midnight, Bob took over the watch from Wally, and sat hunched beside the fire with his rifle across his knees. About half an hour passed. All was silent, and, not dreaming of any danger, he half dozed, his thoughts back on his school days. But suddenly he sat boit upright. An eerie feeling shot to his heart. He felt that he was being watched. All the others in the camp, black and white, were sleeping in front of him. No one was awake, and he knew that none of them could have been watching him.

He tried to shake off the reeling. hut, try as he would, every' second it became stronger.

Was it helind him. Those unseen eyes ... At last he was compelled to turn around.

His blood froze ... behind him, not a yard away, crouched a frightful monster. It was the caricature of a man, about seven feet tall, and its body and long arms were covered with thick, black hair. The great head, like a gorilla's in shape, was thrust forward, its teeth were gleaming, its red eyes fiercely burning. Great hairy hands were extended to clutch him.

With a gasp of horror the boy leapt to his feet. He dropped the rifle, tried to retrieve it ... but the frightful thing was upon him. The hairy hands caught his throat in a deadly grip. All was silent. The eyes burned into his, the dank breath fanned his cheeks... the awful fingers choked and choked. Bob felt that his throat must burst. He struggled, but the brute had him in a leg-hold. A mist of blood spread across the boy's sight. Dimly he saw four other monsters creep out of the jungle and steal up to his sleeping comrades.

One bent over the pigmy Ponkalo. The little fellow started up and looked into the frightful grinning face above him in horror. His lips opened to cry out, but the cry never came ... a great hand closed about his skull, and crushed it to pulp as if it were no more than an egg-shell.

The others were almost up to the white men. Bob was swooning, but he knew that he must warn them to save them from the same dreadful fate as Ponkalo. With his last remaining volt of power he whirled himself about so that the great ape's back was to the fire. He got his feet to the ground and shoved with all his might. The cruel fingers dug deeper, but the monster stepped back. Its feet trod into the red hot embers. It screamed aloud, released its victim, tried to leap out, but fell into the centre of the fire. lts shaggy hair caught ablaze, and screaming with pain the huge thing rushed among its fellows. The flames from the burning animal were transmitted to another.

The din was terrific. The camp awoke instantly. Dr. Holt and Wally grabbed up their rifles. A dozen more of the brutes poured into the clearing, and the white men fired into their midst as rapidly as they could pull the triggers of their repeaters.

This took effect. Yelling and jabbering a sort of language, the monsters fled into the jungle, leaving half their number dead upon the ground. Both black and white men stared after them with fearful eyes. 
Dr. Holt ran to Bob, who lay unconscious beside the fire

"Keep a sharp watch," he called to Wally.

And it was as well that he had said it, for a few minutes later a yelling mob burst from all sides. Two pigmies ran shrieking into the bush, and the other natives turned to follow, but the shrill death cries of those who had gone before halted them.

Wally's rifle was empty. Holt flung his own to him.

"Stand, Wally: I'll take Bob aboard the launch!" he shouted.

The natives followed with a rush. Alone, Wally slood firing into the howling mob of hairy monsters. When his rifle was spent of ammunition, he clubbed it, and seeing that his comrades had reached the launch, battered his way to the river.

Somehow he escaped and reached the launch. Holt was standing over the engine, one hand on the throttle, the other firing a revolver at the mob.

"The anchor, Wally!" he shouted.

Two great brutes leapt on to the deck, but Holt sent them back with a storm of lead.

Fortunately, there was sufficient steam in the boiler to get them out to the middle of the stream, but the launch was very slow.

"Take the wheel," cried the doctor, and ran to stoke the furnace. Then Wally saw a great ape dash out of the group which stood watching in the firelit clearing. It shouted something to the others, and all with a mighty yell, plunged into the water.

There was now no chance of running down stream. Wally pointed the bow against the swifi current. The apes came on, swimming with amazing rapidity ... and all the time, the Seagull, with barely enough steam to move her pistons, was struggling against the current.

Bob, who was lying on the deck, regained his senses. He stared at the fast-approaching mob behind, and then seized an emply rifle. Finding it unloaded, he filled it from his cartridge-belt, and turned the weapon upon them.
With every stroke, the Ape-men were overtaking the launch. Holt had packed the furnace with fuel, but steam was not rising fast enough to allow them to speed away. Magazine after magazine Bob emptied into the on-coming mob, but though many screamed and dropped out of the race, it took little or no effect upon the others.

Dr. Holt came up from the furnace pit. He stared in horror for just one second, and hastened to the engine. There was no hope now the leader of the apes was less than ten yards from the stern, and the launch was crawling, crawling with merciless slowness, against the tide.

Dr. Holt rushed out of the engine-room carrying a tin of kerosene, which they used for cooking. He dumped it near the stern, and ripped out the lid with a jack-knife. In a moment he rushed to the furnace, and came back with a burning stick.

Now the leader of the mob was within two yards of the stern. Another three strokes and his great hairy hands would grasp it. Bob's rifle jammed with the heat of rapid firing, and there was the party at the mercy of a hundred howling Ape-men. Then over the stern Holt flung the kerosene, full in the face of the leading monster, and threw the torch after it. There was a burst of yellow flame. a din of screaming.

The launch was saved. Behind the mob struggled and fought in a sea of fire ... steam slowly came up in the Seagull's boiler. Faster and faster turned the screw. and the launch shot out of danger.

They got some distance up stream, keeping well to the centre of the river, for, while they floated on, the stamp of heavy feet could be heard along the shores.

Dawn came. There was no sign of the Ape-men, but the party knew that red eyes were watching from the leafy walls of the jungle. They cast anchor, and slept till an hour before noon.

"Do you wish to tum back?" asked the scientist of the boys. "You have seen what we must face, if we continue to search for Colin Wills. If you wish to return to the coast, I will take you, and will not blame you. I can return with a stronger force." 
"No fear!" answered Bob, quickly, now fully recovered from the horror of the previous night. "I'll stick!"

"Same here!" cried Wally. "If you're sticking, Doc, I'm with you. We've tons of ammunition, and can put up a great fight. Even if Wills is dead, we can at least take some news of him back to civilisation."

So it was agreed to stay.

"Judging by their methods of attack last night," said the doctor, "those Ape-men are almost human. They seem to possess some language, and have a system of organisation."

At noon the scientist took the bearings with a sextant.

"Good heavens!" he cried. "Boys, we're within five or six miles of the bearings which Wills gave in the gold message!"

This was enlivening news. Not more than an hour afterwards, the Seagull's anchor was hauled up, and the party continued the journey to the south-west. They came to a bend in the river, and rounded it to enter a wide bay. The party was eagerly on the watch, for they knew that they were near to the citadel of the Ape-men. The bay was skirted on the left by a mighty cliff of reddish color, which towered at least two hundred feet above the water.

They stared up at it.

"Ironstone," remarked Holt. "And, look, there are idols at the summit."

The boys followed his indication. Upon the top of the cliff, apparently some feet back from the brink, stood a pair of giant figures. crudely carved out of stone.

"This must be Mobongu," concluded the doctor.

"Look, ship alonga bay, Boss!" shouted a blackboy.

They all looked. There, in a cove, under the cliff, lay a big sieam launch, apparently falling to pieces from neglect.

"That must be the ship of Wills. I wonder if he is still alive," Holt said.

As if in answer to his question, they heard a far-off shout. Wally looked up to the cliff-top, and called excitedly to the others. Between the idols stood the tall figure of a man.

Holt took up his binoculars and surveyed him. He was clad only in a loin-cloth. His hair was long and black, and he wore a heavy beard. .. . But what seized most upon the mind of Dr. Holt was the color of his skin. He was white!

"It must be Wills," cried the doctor, excitedly, "We are not too late."

They waved to him and shouted through cupped hands. The man on the cliff did likewise, but the distance was too great for the sound to carry. There was a pause. Then they saw the man's arms semaphoring.

"Can any of you read that?" asked Holt, quickly. Wally nodded; already he was interpreting the message. He called it out word by word to the others.

"I am Colin Wills, explorer. I am in the hands of a colony of Ape-men."

"Tell him that we found the buzzard, and have come to rescue him." said Holt.

The arms of the man made answer. "Thank you, but the dangers are too great. There are thousands of Ape-men here. If caught, you will be quickly killed. I was captured with two comrades. They were put to death. I have preserved my life only with the aid of a mouth organ, which I play to them. Whenever they turn upon me I play, and they leave me alone. I am now a sort of slave. But go, for the sake of your lives."

"Tell him we won't leave without him, whatever the cost," said the scientist. "Ask if there is some means of scaling the cliff to reach him."

"The cliff is sheer, and there is no means of scaling it," came back the answer. "The Ape-men worship an evil spirit, which they believe to inhabit the waters of this bay. There is a ceremonial ground on the top of the cliff at the back of these statues. No ape will advance within a dozen yards of the brink, for that space is taboo. I have learned their language, and can speak to them and understand them. Behind where I now stand is an altar from which they fling victims to be sacrificed to the spirit of the bay." 
"Can you lower a rope to us?"

"Yes, I can drop down a grass rope. It is not strong enough to support weight, but with it I could take up a rope from you, which will be sufficiently strong. But it is better to wait until night. Their village is less than two hundred yards from the brink of the cliff. The twelve feet space is taboo at ordinary times, but $l$ doubt if it would remain so if they saw a chance to secure fresh white victims. I am paralysed in the right hand and right foot, so that $1 \mathrm{am}$ unable to climb down. If you insist on the rescue someone must climb to the top and lower me."

The comrades signalled back that they would come up to him.

"To-night I will come to the edge and signal to you with a torch when it is safe to ascend." With that, Wills waved a farewell and departed.

There was much argument as to who should make the ascent to the cliff-top. Each one wanted to go, but it was plainly a one-man job. At last they decided to draw lots, and the climbing fell to Bob.

They sat waiting for the night. Occasionally from above came the sound of hoarse cries and shouts, and once they heard the far-off music of a mouth organ. The sun was just about to set when the first happening which demonstrated the hideous dangers before them occurred.

A great hubbub came from the cliff-top. Then suddenly it ceased, and the sound of a log drum floated down to them. A weird chanting joined in the beating of the drum.

"Evidenlly the Ape-men are performing some ceremony," said Dr. Holt.

The chanting and drumming continued. The sun, a great red ball, reached the top of the jungle. Then, suddenly as it had begun, the chanting and drumming ceased. A loud yell rang out. Far above them the Seaguil's party heard a faint, wailing cry, becoming louder, louder.

"Look!" gasped Wally.

Down through the air was hurtling a human form. Its wailings died; it crashed onto a flat rock, half-submerged, some twenty yards out from the base of the cliff. The party looked in horror, saw the water redden and the mutilated body of a pigmy native float for a moment on the surface.

But it was only for a moment. Suddenly a monster alligator leapt forward from the rocky shallows and seized it. There were others; the water seethed to their fighting.

Sickened with disgust, the watchers turned away from the sight and settled down to await the signal from Wills.

It came a little after nine o'clock. The blazing torch waved from the heights of the ironstone cliff. A little while afterwards the grass rope, a weight attached to the end of it, swung over to the launch. It was seized, and the line made fast.

Wills signalled again when he had attached the rope at the top, and Bob, after shaking hands with the doctor and Wally, climbed up. Hand over hand he went, until his arms felt as if they were breaking, and sweat was pouring from his body. But he reached the summit, and Colin Wills, almost hysterical with joy, helped him over the edge.

Within a few minutes Bob had fastened a canvas sling around Wills's body, and, with the strain taken by a smooth piece of jutting rock, lowered him to the launch. A winking lamp told him that all had gone well. But Bob's curiosity got the better of him at the moment of departure. He looked around. About two hundred yards away a dozen great fires at the foot of a cliff showed where the village of the Ape-men was. Twenty or thirty black blotches on the dimly-lighted wall marked cave entrances. Evidently the Ape-men were some missing species of primitive men. He could see one or two slouching figures near the fires, but evidently he was safe.

As Wills had said, there was a twelve-foot space between the edge of the cliff and the remaining ground, and it was marked off by a line of small idols. Curious to see what they looked like, Bob approached them. He touched one. It was smooth and cold, like metal. Behind one, as he thought, out of sight of the village, he struck a match.

To his amazement he found that the idol, though very 
rudely constructed, was made of solid gold. A wave of excitement swept over him. He shoved the small idol; it fell with a dull clang on to the floor of ironstone.

"I'll pull up the rope and lower it to the launch," he thought. He crossed to the precipice and tugged at the rope to show that he wanted the other end freed. Those below, guessing what he wanted done, released the rope, and Bob hauled it up.

It did not take him long to drag the idol to the brink and lower it down to the launch. And the success gave him courage. He dragged another and lowered it, and then went back for a third . . . but he had stayed too long!

The cunning apes, having heard the sounds and scented a different presence to that of Wills, had stolen across from the village. As Bob laid hands on the third idol, a dozen of the monsters leapt upon him. He fought to gain the sacred space near the brink, but he failed. There was a great uproar. Hundreds from the village rushed out to meet the captors, and, yelling for joy, careered around them. Bob was like a baby in the fierce hold of the hairy giants. He struggled, but they dragged him away towards the caves. He expected instant death, but, instead, the Ape-men, amid a great ciamor of discussion, flung him into a cave, and ten or a dozen sat in guard at the entrance.

His comrades on the launch, two hundred feet below, had heard the uproar, and when for minutes, the rope hung slack. they realised that the worst had happened.

"What can we do?" asked Dr. Holt, aghast.

Colin Wills stood watching the cliff at the fatal spot... the place at which he had escaped from years of captivity at the expense of the boy who had saved him. He shook his head sadly.

"I don't know," he muttered. "I fear there is no escape for him. They will keep him prisoner under a close guard until sunset to-morrow, then they will bring him to the altar and hurl him over to their cursed god. That they always do with their prisoners. 1, alone, of all of them, escaped."

The others shuddered at remembrance of the death wail of the unfortunate victim of the last sunset ceremony. For hours they waited and tried to plan. There was no other approach to the top of the ironstone cliff than the one by which Bob had gone. To get to the rear, miles and miles of dense jungle had to be penetrated, jungle, thick with those hideous monsters. Then the rear approach was almost as inaccessible as the front, except for closelyguarded passes.

Both Holt and Wally climbed to the summit at different times, but they saw the absolute futility of trying to make a nush rescue.

All through the night they sat pondering upon some mode of rescue, for they were determined not to give up, even at the cost of their lives. It was at three o'clock in the morning that Dr. Holt came up from the stern, where he had been sitting for hours thinking.

"I've got a way out," he said quietly. "And l think it'll work."

He went into his cabin, and took from the medicine chest a bottle of rochelle salts, a medicine which is used in fever. "Have you ever heard of a rochelle crystal?" he asked.

The others shook their heads.

"Then you soon will," he said, with a quiet laugh. He seemed suddenly to have assumed such great cheerfulness. that the spirits of the others rose at once.

Dr. Holt took the rochelle salts to the galley, turned out two small round pepper tins of their contents, and replaced it with the stuff he had brought. To each tin he added a little water, and then placed them on the oil stove to heat. The salt melted. As soon as it was fluid and had dissolved in the very small quantity of water he had added, Dr. Holt placed the lids on the tins, and dropped them into a bucket of cold water to cool.

He took them out after a while and carefully shook out the salt, which in each case had solidified to form a cylindrical crystal.

"This rochelle sait is funny stuff," he said. "It is known in chemistry as a double-salt, and has a peculiar atomic structure. One of the tricks it will play if arranged in a 
certain manner, is to act as a transmitter and receiver of sounds. And more than that, it amplifies the sound one hundred times."

He took two aluminium saucepans and cut four discs from them with a tin opener. These discs he placed one at each end of the crystals, and fastened each disc to the one at the other end by means of a pair of thumb screw's, one on either side of the crystal. This done, he went to his cabin and fished a human skull from his collection and a piece of red cloth.

"I'm going up to the cliff top," he said, when he came out. "Pay out the wire on this coil for me, Wally." At the summit of the cliff he placed the one crystal he had brought inside the skull, fastened a wire to each aluminium plate, and set the skull on the ironstone floor directly opposite the altar.

He came back at once, when it was almost dawn. and finished off the setting by connecting the other crystal to a pair of dry cells and placed it inside an open kerosenetin.

Even then, he was not finished. All day he worked. First he went out in the dinghy to the base of the iron cliff, and drove a brass bolt into a crack. To this bolt he connected a stout, insulated wire. On board the launch he disconnected the big 110-volt dynamo, which supplied the launch with light, and hooked it up with a 4-kilowatt closed-core spark coil, which he robbed from his radio transmission set.

At six o'clock in the evening, he donned an oilskin coat and a pair of rubber sea-boots, and bade Wally bind uncovered copper wires around his waist and arms and legs. He then took out a long coil of insulated wire and connected one end of it to the spark coil and the other to the wire about his body.

"Now, listen," he said to the others. "As soon as the ceremony commences, I'm going up to the top of the cliff. As soon as I leave the launch, Wills, I want you to speak into the kerosene-tin. Tell them that you are the spirit of the river, who is coming up to pay them a visit. Tell them you don't w'ant the victim thrown down, but that you are coming up for him. Say what else you like, and make it awe-striking. Begin in a low voice and raise it louder and louder while I climb up. Shout when you see me reach the top. Your voice will be reproduced at the other end in the skull, and it will be magnified a hundred times. Tell them that if they touch the river god they will be struck dead. Now you, Wally, as soon as I reach the top switch on the coil. Understand? You'd better tell them, while you're about it, Wills, to quit feeding any more victims to you."

Dr. Holt finished off his weird equipment with a brace of lyddite bombs, which he had prepared with concussion fuses.

At half-past six the ceremony above began. The howling and shouting continued for about fifteen minutes. The sun was due to set at seven. Fifteen minutes the men in the launch waited for the heating of the log drums with racing hearts. It came ... and with it the eerie chanting.

Dr. Holt rose and shook hands with his comrades. No one spoke, it was not a time for talking. Dr. Holt seized the rope, and began to climb. and as his feet left the deck, Colin Wills began to speak into the kerosene-tin in the weird clipping tongue of the Ape-men.

"Nya, Nya, Nya, ye hairy ones, Nya ... Nya, "tis the god of the waters who speaks unto thee. Nya, Nya ..." The rigmarole went on, according to the orders of Dr. Holt.

As the doctor climbed higher, the water-god's voice rose also, until as if by magic the sounds on the cliff-top ceased. Higher and higher the intrepid Holt climbed. Louder and louder grew the voice of the river god, and those on the launch began to hear the words spoken into the tin repeated from above in strident tones.

The sun was low over the jungle when the wire-encircled river god climbed over the edge of the precipice. He raised his hand to the watching Wally, and the dynamo was switched on to him. A thousand Ape-men stared at him in silence. His heart was beating rather wildly for a river god, who has come to meet his people, but Holt did not flinch. He waiked straight to Bob, who lay upon the altar bound with thongs of grass rope.

The din of Wills' voice shrieked from the skull, and Holt moved his lips to pretend that the sound came from him. Stock still stood the red-cyed mob of half-human monsters. 
Holt drew a knife and slashed Bob's bonds.

The boy rose. But the sight was too much for the Apemen. With a howl of fury a pair of hairy brutes rushed at the evil spirit who was depriving them of their only sport. They little realized that they were bearing the negative current of the Seagull's dynamo from the iron cliff with their feet and bearing it to the positive with their naked hands.

The pair seized Holt with their hairy paws ... one shriek, a flash of blue light, and they fell, writhing in death at the foot of the altar. Bob stared in amazement.

"Don't touch me," Holt shouted to him above the din of the crystal. "Now go for your life."

Bob jumped from the altar. Again the mob rushed while the crystal yelled of sudden death and punishment for those who disobeyed. Holt leaped in between Bob and the brutes that tried to seize him.

Blue flashes and shrieks of agony as the hairy bodies closed the circuit between Holt and the electrifjed ironstone. A dozen fell twisted and dead. The others baulked.

"Go for your life, Bob; 1 can hold the devils!" yelled Holt. The boy obeyed. He climbed over the edge. Holt unhitched his bombs just as the furious mob surged forward again. He flung one to right and the other to left into the thick of the hairy mob. Two loud detonations rent the air. There was one awful long-drawn howl, and the Ape-men fled to their caves.

In less than fifteen minutes Holt regained the launch. His comrades seized and hugged him with delight.

The two golden idols which Bob had stolen at so great a risk were sufficient. Not ten minutes after the arrival of Holt, Wally hauled up the anchor, and the Seagull steamed down the Hidden River as fast as her screw would thrust her away from the home of the Ape-men of Mobongu.

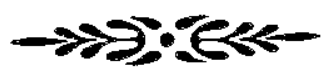

